\title{
Nutritional intake and its association with educational achievement in high-school students in Islamic Republic of Iran
}

\author{
Akram Kooshki ${ }^{1}$, Maryam Mohammadi ${ }^{2}$ and Mahmood Rivandi ${ }^{3}$ \\ ${ }^{1}$ Department of Nutrition and Biochemistry, Faculty of Medicine, Sabzevar University of Medical Sciences, Sabzevar, Islamic Republic of Iran. \\ ${ }^{2}$ School of Health, Shahid Beheshti University of Medical Sciences, Tehran, Islamic Republic of Iran (Correspondence to: Maryam Mohammadi: \\ M_Mohammadimm@yahoo.com). ${ }^{3}$ Department of Organic Biochemistry, Sabzevar University of Applied Sciences \& Technology, Sabzevar, Islamic \\ Republic of Iran.
}

\begin{abstract}
Background: Inadequate food intake can affect learning and memory. Studies on the nutrient intake of adolescents in Sabzevar are lacking.

Aims: This study assessed the nutrient intake of high-school students in Sabzevar and its association with academic attainment.

Methods: This cross-sectional study was conducted on 800 of 8000 high-school students in Sabzevar. Stratified sampling was used. Demographic data and academic information were collected and the parents of the students completed a food frequency questionnaire which included 189 food items. The students' weight and height were measured using standard methods. Each food was coded using Nutritionist IV software and mean values of nutrients ( 13 vitamins/minerals, 4 food types and total energy) were calculated.

Results: The mean body mass index of female and male students was 20.3 (SD 2.7$) \mathrm{kg} / \mathrm{m} 2$ and 19.5 (SD 3.2) kg/m2 respectively. The intakes of energy, vitamins A, C, D, folic acid, calcium, iron and zinc were significantly lower than the dietary reference intake $(\mathrm{P}<0.05)$. A statistically significant correlation was seen between iron intake and academic scores in female students $(\mathrm{P}<0.05)$ but not for any other nutrient.

Conclusions: The intake of most nutrients in high-school students in Sabzevar was lower than the dietary reference intake. Nutrition education and nutritional support strategies are recommended to improve the nutritional status of these students.
\end{abstract}

Keywords: Adolescent; Students; Nutritional status; Recommended dietary allowances, Iran

Citation: Kooshki A; Mohammadi M; Rivandi M. Nutritional intake and its association with educational achievement in high-school students in Islamic Republic of Iran. East Mediterr Health J. 2018;24(6):532-537. https://doi.org/10.26719/2018.24.6.532

Received: 07/03/16; accepted: 29/03/17

Copyright (C) World Health Organization (WHO) 2018. Some rights reserved. This work is available under the CC BY-NC-SA 3.o IGO license (https:// creativecommons.org/licenses/by-nc-sa/3.o/igo).

\section{Introduction}

Adolescents have received considerable research attention in the past decade mainly because of the sheer size of this population (1). About $85 \%$ of adolescents live in developing countries and account for about one third of the national populations those countries (2). Nearly $70 \%$ of children and adolescents suffering from malnutrition live in Asia (3). The increasing incidence of childhood obesity and the socioeconomic and public health burden it causes is a real threat for developing countries (4). Inappropriate nutritional habits and unhealthy lifestyles are important health risk factors in this vulnerable group and may eventually lead to chronic diseases in adulthood $(5,6)$. Obesity during childhood and adulthood is a fast emerging problem in the Islamic Republic of Iran and the highest prevalence of obesity is observed among teenagers; it is reported that $12.2 \%$ of adolescents are overweight and $3.9 \%$ obese (7). Other studies have also shown the increasing prevalence of overweight and obesity in children and adolescents in the country $(8,9)$. Another Iranian study has shown that a lack of adequate food is associated with impaired concentration and learning, and academic misconduct (10).

Studies suggest that learning and memory are influenced by diet, not only during childhood but also in adolescence. For example, omega-3 fatty acids reduce the ageing-related reduction in the memory (11). In an Iranian study, temporary starvation or attendance without eating breakfast and fasting affected precision, concentration and academic ability (12). On the other hand, Swedish students eating fish high in omega-3 fatty acids were more likely to have good school grades (13).

There is a lack of information about the nutrition and nutrient intake of adolescent students in Sabzevar. Therefore, we aimed to assess the nutritional intake of high-school students and its association with academic attainment.

\section{Methods}

\section{Study design and sample}

This cross-sectional study was conducted in Sabzevar, Islamic Republic of Iran. The sample included 800 high- 
schools students aged 14 to 18 years in Sabzevar. The sample was selected from the 8000 high-school students in Sabzevar, $10 \%$ of the high-school population in Sabzevar.

The Department of Education of gave permission for the study and helped with coordination. All 50 high schools in Sabzevar were identified and listed (30 girls' and 20 boys' schools) and 25 schools (15 girls' and 10 boys' schools) were selected by a stratified sampling method based on a random method. In each school, participants of each class (first to fourth grades of high school) were selected using stratified sampling according to size. For example, from a class of 40,10 students were selected and from a class of 30, 7 were selected. The study was explained to the students and their parents' written consent was obtained. No students declined to participate and all responded to questionnaire.

\section{Study tool and data collection}

Data were collected in a questionnaire which had two parts. The first recorded information about demographic factors (weight, height, age, sex), and the student's scores in school subjects (mathematics, physics, chemistry and biology) and overall grade point average (GPA). The mean subject and GPA scores were taken from the students' academic records. Weight was measured in light clothing and without shoes using a precision digital scale (Seca) to the nearest $100 \mathrm{~g}$, and height was measured with a tape measure to the nearest $1 \mathrm{~cm}$. Body mass index (BMI) was calculated (weight $/ \mathrm{metre}^{2} ; \mathrm{kg} / \mathrm{m}^{2}$ ).

The second part was a quantitative food frequency questionnaire to measure dietary intake. The content validity of the instrument was determined by calculating the content validity ratio coefficient and content validity index (14). The questionnairewas given to a panel of experts in the field of nutrition and health. They were asked to rate each item as: necessary, useful but unnecessary, unnecessary. After the validity and reliability process, 189 foods were included. The content validity index value was 0.85 , which represents an acceptable validity of the instrument. Internal consistency of the questionnaire was evaluated with Cronbach alpha (0.91).

Before the study began, training was given to parents on how to complete the food frequency questionnaire and measure food and beverage intake. Participants determined how many times they ate the food and how much they ate each time in the past month. The amounts for each food were converted to grams using household measures guidelines (15). Foods were coded according to Nutritionist IV and the students' diets were analysed using Nutritionist IV software (N Squared Computing, California, USA). The mean food intake of the students was compared with the daily references intake values (16).

\section{Statistical analysis}

SPSS, version 16 was used for data analysis. Data for nutrient intake are presented as mean and standard deviation (SD). The Pearson correlation test was used to compare nutrient intake and GPA scores and the t-test was used to compare the food data with standard values for both sexes. $P<0.05$ was considered statistically significant

\begin{tabular}{|c|c|c|c|}
\hline Nutrient & Mean (SD) & DRI & P-value \\
\hline Energy (Kcal/d) & $2160(675.7)$ & 2400 & 0.001 \\
\hline Protein $(\mathrm{g} / \mathrm{d})$ & $55.5(25.21)$ & 52 & 0.16 \\
\hline Carbohydrates (g/d) & $308.38(90.3)$ & 130 & 0.0001 \\
\hline Fat $(\mathrm{g} / \mathrm{d})$ & $34.10(68.5)$ & $25-30 \%$ & 0.07 \\
\hline Fibre $(\mathrm{g} / \mathrm{d})$ & $5.23(4.25)$ & 38 & 0.0001 \\
\hline Vitamin A (IU/d) & $920.1(875.2)$ & 3000 & 0.0001 \\
\hline Vitamin D (IU/d) & $150.15(90.85)$ & 200 & 0.0001 \\
\hline Vitamin $\mathrm{E}(\mathrm{mg} / \mathrm{d})$ & $6.35(6.45)$ & 15 & 0.0001 \\
\hline Vitamin C (mg/d) & $30.5(42.3)$ & 75 & 0.0001 \\
\hline Vitamin $\mathrm{Bl}(\mathrm{mg} / \mathrm{d})$ & $1.0(0.5)$ & 1.2 & 0.12 \\
\hline Vitamin B2 (mg/d) & $1.1(0.6)$ & 1.3 & 0.14 \\
\hline Vitamin $\mathrm{B}_{3}(\mathrm{mg} / \mathrm{d})$ & $14.7(6.9)$ & 16 & 0.21 \\
\hline Vitamin B6 (mg/d) & $1.2(0.7)$ & 1.3 & 0.75 \\
\hline Vitamin B9 (folate $(\mu \mathrm{g} / \mathrm{d})$ & $228(125.72)$ & 400 & 0.0001 \\
\hline Vitamin B $12(\mu \mathrm{g} / \mathrm{d})$ & $2.6(1.6)$ & 2.4 & 0.18 \\
\hline Calcium (mg/d) & $345.5(575.15)$ & 1300 & 0.0001 \\
\hline $\operatorname{Iron}(\mathrm{mg} / \mathrm{d})$ & $17.3(8.5)$ & 11 & 0.01 \\
\hline $\operatorname{Zinc}(\mathrm{mg} / \mathrm{d})$ & $4.5(8.0)$ & 11 & 0.01 \\
\hline
\end{tabular}

$S D=$ standard deviation; $d=$ day. 


\section{Ethical considerations}

The study was approved by the Ethics Committee of Sabzevar University of Medical Sciences.

\section{Results}

Of the 800 students included in this study, 500 were girls and 300 boys. The mean BMI of the girls was 20.3 (SD 2.7) $\mathrm{kg} / \mathrm{m}^{2}$ and of the boys was 19.5 (SD 3.2) $\mathrm{kg} / \mathrm{m}^{2}$. Based on BMI, $10.7 \%$ of the girls and $15.5 \%$ of the boys were underweight (BMI $\left.<18.5 \mathrm{~kg} / \mathrm{m}^{2}\right), 13.2 \%$ of the girls and $9 \%$ of the boys were overweight (BMI: $25-29.9 \mathrm{~kg} / \mathrm{m}^{2}$ ) and $3 \%$ of the boys were obese $\left(\mathrm{BMI} \geq 30 \mathrm{~kg} / \mathrm{m}^{2}\right)$; none of the girls was obese.

The mean intake of energy and nutrients of the boys and girls is shown in Tables 1 and 2 respectively. Compared with the recommended daily values, the energy and nutrient intake of the students was significantly lower for vitamins A, D and C, folic acid and calcium ( $P=0.0001)$, and iron and zinc $(P=0.01)$. A statistically significant association was found between iron intake and average grades in the academic subjects and GPA score of the girls $(P=0.0001)$ but not the boys $(P=0.001)$.

The energy and nutrient intake of boys compared with girls is shown in Table 3. Energy and zinc intake was significantly lower in the girls than the boys, while vitamin A was significantly higher in girls than boys.

\section{Discussion}

Our study showed that intake of nutrients, including energy, vitamin A, C, D, folic acid, calcium, iron and zinc in the students was lower than the recommended daily amounts of food. Our results are consistent with another
Iranian study on 396 teenage girls in Kerman that showed energy, fat, vitamin A and calcium intake was insufficient (17). Similarly, a study in Poland reported that the daily intake of calcium, iron, zinc and copper in adolescent aged 16 to 19 years was low (18). Also, in the United States, the National Growth and Health Study data showed that the majority of girls had inadequate intakes of calcium, magnesium, potassium, and vitamins D and E (19). Vitamin C deficiency has also been reported among students $(20,21)$, which is consistent with the findings of our study. A lack of nutrients appears to be common in adolescents and the students in our study were no exception.

In our study, energy and zinc intake of girls was significantly lower than boys but vitamin A intake was significantly which may indicate a lower intake of meat and higher intake of vegetables in girls.

Our findings also showed a significant relationship between iron intake and academic subject/GPA scores in girls. Our result is consistent with a study on highschool girls in Gonabad (22) which showed that 16 weeks of iron supplementation significantly increased the average learning score (speed and accuracy) in the experimental group compared with the control group of students, suggesting iron deficiency among girls has an adverse effect on learning. A meta-analysis of randomized controlled trials that assessed the effects of micronutrient-fortified foods on cognitive function found that the micronutrient intake of iron, zinc, iodine, vitamin A had a beneficial effect on short-term memory and working memory performance in children aged 5-15 years (23). In a study of children aged 6-16 years (5 365 children), high levels of serum folate were associated with

\begin{tabular}{|c|c|c|c|}
\hline Nutrient & Mean (SD) & DRI & P-value \\
\hline Energy (kcal/d) & $1920(565.15)$ & 2200 & 0.001 \\
\hline Protein (g/d) & $50.1(20.3)$ & 46 & 0.06 \\
\hline Carbohydrates (g/d) & $308.38(90.3)$ & 130 & 0.0001 \\
\hline Fat (g/d) & $30.3(60.8)$ & $25-30 \%$ & 0.15 \\
\hline Fibre $(\mathrm{g} / \mathrm{d})$ & $5.25(4.10)$ & 26 & 0.0001 \\
\hline Vitamin A (Iu/d) & $1100.1(955.2)$ & 2300 & 0.0001 \\
\hline Vitamin D (Iu/d) & $110.5(80.85)$ & 200 & 0.0001 \\
\hline Vitamin E (mg/d) & $5.45(4.35)$ & 15 & 0.0001 \\
\hline Vitamin C (mg/d) & $30.5(42.3)$ & 65 & 0.0001 \\
\hline Vitamin B1 (mg/d) & $0.9(0.5)$ & 1 & 0.15 \\
\hline Vitamin B2 (mg/d) & $1.0(0.3)$ & 1 & 0.98 \\
\hline Vitamin B3(mg/d) & $13.2(1.2)$ & 14 & 0.17 \\
\hline Vitamin B6 (mg/d) & $1.12(0.63)$ & 1.2 & 0.21 \\
\hline Vitamin B9 (folate) $(\mu \mathrm{g} / \mathrm{d})$ & $284.22(140.10)$ & 400 & 0.0001 \\
\hline Vitamin B12 ( $\mu \mathrm{g} / \mathrm{d})$ & $2.5(1.5)$ & 2.4 & 0.83 \\
\hline Calcium (mg/d) & $345.5(575.15)$ & 1300 & 0.0001 \\
\hline Iron (mg/d) & $9.5(15.5)$ & 15 & 0.01 \\
\hline Zinc (mg/d) & $3.2(6.0)$ & 9 & 0.01 \\
\hline
\end{tabular}

$S D=$ standard deviation $; d=$ day . 


\begin{tabular}{|c|c|c|c|}
\hline Nutrient & $\begin{array}{c}\text { Males } \\
\text { Mean (SD) }\end{array}$ & $\begin{array}{c}\text { Females } \\
\text { Mean (SD) }\end{array}$ & P-value \\
\hline Energy (kcal/d) & $2160(675.7)$ & $1920(565.15)$ & 0.0001 \\
\hline Protein (g/d) & $55.5(25.21)$ & $50.1(20.3)$ & 0.18 \\
\hline Carbohydrates (g/d) & $308.38(90.3)$ & $308.38(90.3)$ & 0.68 \\
\hline Fat (g/d) & $34.10(68.5)$ & $30.3(60.8)$ & 0.49 \\
\hline Fibre $(\mathrm{g} / \mathrm{d})$ & $5.23(4.25)$ & $5.25(4.10)$ & 0.39 \\
\hline Vitamin A (IU/d) & $920.1(875.2)$ & $1100.1(955.2)$ & 0.001 \\
\hline Vitamin D (IU/d) & $150.15(90.85)$ & $110.5(80.85)$ & 0.05 \\
\hline Vitamin E (mg/d) & $6.35(6.45)$ & $5.45(4.35)$ & 0.11 \\
\hline Vitamin C (mg/d) & $30.5(42.3)$ & $30.5(42.3)$ & 0.66 \\
\hline Vitamin $B 1$ (mg/d) & $1.0(0.5)$ & $0.9(0.5)$ & 0.56 \\
\hline Vitamin B2 (mg/d) & $1.1(0.6)$ & $1.0(0.3)$ & 0.09 \\
\hline Vitamin B3(mg/d) & $14.7(6.9)$ & $13.2(1.2)$ & 0.16 \\
\hline Vitamin B6 (mg/d) & $1.2(0.7)$ & $1.12(0.63)$ & 0.23 \\
\hline Vitamin B9 (folate) ( $\mu \mathrm{g} / \mathrm{d})$ & $228(125.72)$ & $284.22(140.10)$ & 0.06 \\
\hline Vitamin B12 ( $\mu \mathrm{g} / \mathrm{d})$ & $2.6(1.6)$ & $2.5(1.5)$ & 0.67 \\
\hline Calcium (mg/d) & $345.5(575.15)$ & $345.5(575.15)$ & 0.71 \\
\hline Iron (mg/d) & $17.3(8.5)$ & $9.5(15.5)$ & 0.07 \\
\hline Zinc (mg/d) & $4.5(8.0)$ & $3.2(6.0)$ & 0.0001 \\
\hline
\end{tabular}

$S D=$ standard deviation $; d=$ day .

a better learning score and better test scores, while serum levels of vitamin B12 did not show such a relationship (24). A study in 2013 also found that the omega-3 fatty acid, docosahexaenoic acid, affected behaviour, memory and brain activity because of its effect on brain development (25). In addition, studies have shown that the lack of an adequate supply of nutrients and malnutrition impaired concentration and learning and was associated with poor academic performance $(9,26)$, and a study in Malaysia also reported that nutritional status and parents' education are factors that could improve academic performance of children (27).

However, in an Iranian study in Kashan, no statistically significant relationship was seen between malnutrition and mathematics, science and spelling scores in elementary school students (28). Overall, the results of such studies, suggest that adequate nutritional support in school can promote children's growth and educational achievement.

\section{Conclusion}

The findings of our study show that the intake of many nutrients in high-school students in Sabzevar is lower than the recommended daily intake. Considering the important role of nutrition in the health and academic performance of students, nutrition education and nutritional support strategies are recommended to raise awareness and improve the nutritional and academic status of students. These could include the provision of snacks in schools and supplementation nutrition such as iron. A clinical trial to better evaluate the relationship between nutrient intake and individual student achievement should be conducted. Future studies should replicate our analysis in other young populations and further investigate how health-related behaviour influences cognitive and academic outcomes.

\section{Acknowledgements}

We thank the Education Department of Sabzevar for their cooperation and also the students who participated in our study.

Funding: None.

Competing interests: None declared. 


\section{Apport nutritionnel et résultats scolaires chez des élèves du secondaire en République islamique d'Iran}

\section{Résumé}

Contexte: Un apport alimentaire insuffisant peut influencer négativement les processus d'apprentissage et de mémorisation. Il n'existe pas d'études sur l'apport nutritionnel des adolescents à Sabzevar.

Objectifs : L'étude a évalué l'apport nutritionnel d'élèves du secondaire à Sabzevar, ainsi que son association avec les résultats scolaires.

Méthodes : La présente étude transversale a été menée auprès de 800 élèves du secondaire sur 8000 à Sabzevar. La méthode d'échantillonnage stratifié a été appliquée. Des données démographiques et des informations académiques ont été recueillies, et les parents des élèves ont rempli un questionnaire de fréquence de consommation qui incluait 189 produits alimentaires. Le poids et la taille des élèves ont été mesurés à l'aide de méthodes standardisées. Chaque aliment a reçu un code attribué par le logiciel de nutrition Nutritionist IV et les valeurs moyennes des nutriments (13 vitamines/ minéraux, quatre types d'aliments et l'énergie totale) ont été calculées.

Résultats : L'indice de masse corporelle moyen des élèves de sexe féminin et masculin était de 20,3 kg/m2 (ET 2,7) et $19,5 \mathrm{~kg} / \mathrm{m} 2$ (ET 3,2) respectivement. Les apports en énergie, en vitamines A, C et D, en acide folique, en calcium, en fer et en zinc étaient significativement moins élevés que les apports nutritionnels conseillés $(p<0,05)$. Une corrélation statistiquement significative a été observée entre l'apport en fer et les résultats scolaires des élèves de sexe féminin $(p<0,05)$, ce qui n'était pas le cas pour les autres nutriments.

Conclusions : Pour la plupart des nutriments, les apports étaient plus bas que les apports nutritionnels conseillés chez les élèves du secondaire de Sabzevar. Une éducation nutritionnelle et des stratégies d'appui dans ce domaine sont recommandées afin d'améliorer l'état nutritionnel de ces élèves.

$$
\text { ألمرم كوشكي، مريم محمدي، محمود ريوندي الغذائي وارتباطه بالتحصيل التعليمي في صفوف طلاب المدارس العليا في جمهورية إيران الإسلامية }
$$

الخلفية: يمكن أن يؤثر التناول غير الكافي للطعام على التعلمّ والذاكرة. وثمة نقص في الدراسات المتعلقة بالمدخول الغذائي للمر اهقين في سابزيفار. الأهداف: عمدت هذه الدراسة إلى تقييم المدخول الغذائي لطلاب المدارس الثانوية في سابزيفار وارتباطه بالتحصيل الأكاديمي.

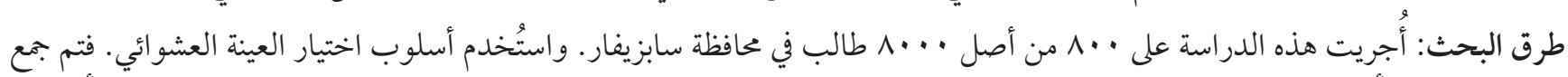

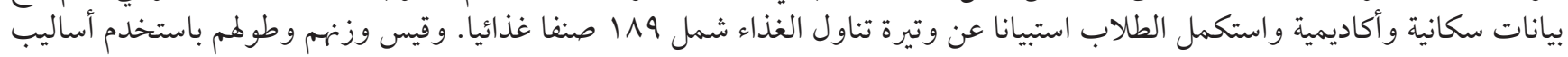

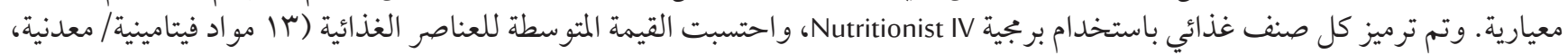
وع أنواع غذائية، وإجمالي الطاقة) وترل فين.

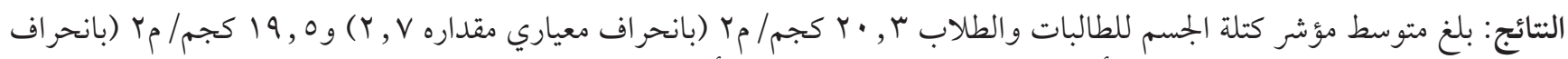

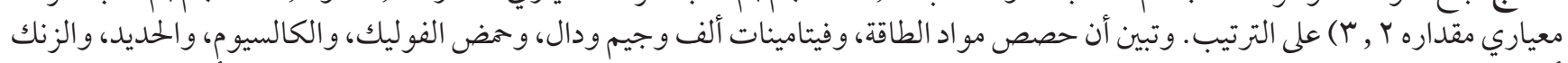

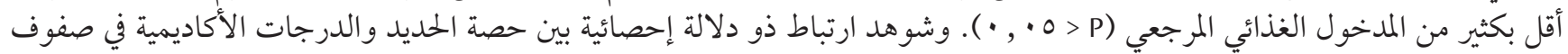

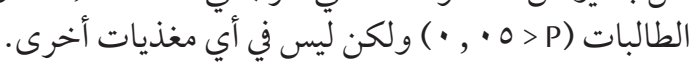

الاستنتاجات: تبين انخفاض مدخول معظم المغذيات في صفوف طلاب المدارس العليا في محافظة سابزيفار مقارنة بالمدخول الغذائي المرجعي.

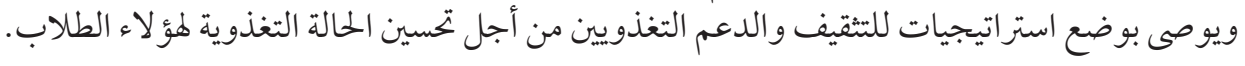

\section{References}

1. Richter LM. Studying adolescence. Science. 2006 Jun 30;312(5782):1902-5. PMID:16809526

2. Focus on. Demographic trends for adolescents: Ten key facts. UNICEF (www.unicef.org/sowc2011/pdfs/Demographic-Trends.pdf, accessed 15 March 2018).

3. Abedi G, Mohamadpour A, Rostami F, Ahmadinia F, Rajabi M. Study of consumption pattern of food and obesity of female students of Mazandaran University of Medical Sciences. J Mazandaran Univ Med Sci. 2011; 20(80):77-80.

4. Djalalinia S, Moghaddam SS, Peykari N, Kasaeian A, Sheidaei A, Mansouri A, et al. Mortality attributable to excess body mass index in Iran: Implementation of the comparative risk assessment methodology. Int J Prev Med. 2015 Nov 4; 6:107. PMID: 26644906 
5. Eisenmann JC. Physical activity and cardiovascular disease risk factors in children and adolescents: An overview. Can J Cardiol. 2004;20:295-301.

6. Bibbins-Domingo K, Coxson P, Pletcher MJ, Lightwood J, Goldman L. Adolescent overweight and future adult coronary heart disease. N Engl J Med. 2007 Dec 6;357(23):2371-9. PMID:18057339

7. Torabi Z, Amiraslani T, Falakaflaki B. [Prevalence of obesity in 12-14 year old children in Zanjan, Iran and some related factors]. J Mazandaran University of Medical Sciences. 2017;26(145):122-32. [in Farsi]

8. Jafarzadeh S, Mohammad Khan Kermanshahi S, Khani Jeihooni A. Effect of comprehensive health promotion program on quality of life, weight, and physical activity among Iranian overweight school-age girls. Int J Pediatr. 2017;5(4):4671-81.

9. Miri SF, Javadi M, Lin CY, Irandoost K, Rezazadeh A, Pakpour A. Health related quality of life and weight self-efficacy of life style among normal-weight, overweight and obese Iranian adolescents: a case control study. Int J Pediatr. 2017;5(11):5975-84.

10. Soheili Azad AA, Nourjah N, Norouzi F. [Survey of the eating patterns of elementary students in Langrood]. J Guilan University of Medical Sciences. 2007;16 (62):36-41. [In Farsi]

11. Stangl D, Thuret S. Impact of diet on adult hippocampal neurogenesis. Genes Nutr. 2009; (4):271-82. PMID:19685256

12. Alavi Naeini AM, Jazayeri A, Moghaddam N, Afrooz Gh A, Behboodi M. Effects of taking snacks on the learning ability and educational achievement of elementary school children. Tehran Univ Med J. 2000; 58(1):38-44.

13. Åberg MA, Åberg N, Brisman J, Sundberg R, Winkvist A, Torén K. Fish intake of Swedish male adolescents is a predictor of cognitive performance. Acta Paediatr. 2009 March;98(3):555-60. PMID:19006530

14. Lawshe CH. A quantitative approach to content validity. Person Psychol. 1985;28(4):563-75.

15. McCord MT, Klein JD, Foy JM, Fothergill K. School-based clinic use and school performance. J Adolesc Health. 1993 Mar;14(2):918. PMID:8476879

16. Alavi Naeini AM, Jazayeri A, Chamri M, Hamedi SJ. [Comparison of the nutritional status of adolescent girls in the secondary schools of two educational districts of Kerman, Iran]. Payesh. 2008;7(3):287-93. [In Farsi]

17. Alavi Naeini AM, Jazayeri A, Chamri M, Hamedi SJ. [Comparison of the nutritional status of adolescent girls in the secondary schools of two educational districts of Kerman, Iran]. Payesh. 2008;7(3):287-93. [In Farsi]

18. Seidler T, Ksiazek J, Sobczak A.Rocz Panstw Zakl Hig. Determining levels of mineral consumption from foodstuff sources in the daily diets of adolescent students living in Kamień Pomorski. A pilot study. Rocz Panstw Zakl Hig. 2013;64(4):309-15. PMID: 24693716

19. Bradlee M, Singer M, Qureshi M, Moore L. Food group intake and central obesity among children and adolescents in the Third National Health and Nutrition Examination Survey (NHANES III). Public Health Nutr. 2010 Jun;13(6):797-805. PMID:19772691

20. Gan R, Eintracht S, Hoffer LJ. Vitamin C deficiency in a university teaching hospital. J Am Coll Nutr. 2008 Jun;27(3):428-33. PMID:18838532

21. Oliveras Lopez MJ, Nieto Guindo P, Agudo Aponte E, Martinez Martinez F, Lopez Garcia de la Serrana H, Lopez Martinez MC. Evaluacion nutricional de una población universitaria [Nutritional assessment of a university population]. Nutr Hosp. 2006 MarApr;21(2):179-83. PMID:16734070

22. Salari H, Reihani T. [Influence of nutrition training and weekly iron supplementation on the rate of girl student learning of Gonabad high schools]. Ofogh-e-Danesh. 2004;10(2):11-5. [In Farsi]

23. Khor GL, Misra S. Micronutrient interventions on cognitive performance of children aged 5-15 years in developing countries. Asia Pac J Clin Nutr. 2012;21(4):476-86. PMID:23017305

24. Nguyen CT, Gracely EJ, Lee BK. Serum folate but not vitamin B-12 concentrations are positively associated with cognitive test scores in children aged 6-16 years. J Nutr. 2013 Apr;143(4):500-4. PMID:23390191

25. Kuratko CN, Barrett EC, Nelson EB, Salem N Jr. The relationship of docosahexaenoic acid (DHA) with learning and behavior in healthy children: a review. Nutrients. 2013 Jul;5(7):2777-810. PMID:23877090.

26. Alaimo K, Olson CM, Frongillo EA Jr. Food insufficiency and American school-aged children's cognitive, academic, and psychosocial development. Pediatrics. 2001 Jul;108(1):44-53. PMID:11433053

27. Hamid JJ, Amal MK, Hasmiza H, Pim CD, Ng LO, Wan MW. Effect of gender and nutritional status on academic achievement and cognitive function among primary school children in a rural district in Malaysia. Malays J Nutr. 2011; 17(2):189-200. PMID:22303573

28. Sarbouloki SH, Nikoei Nejad H, Sarafraz F, Ahyazadeh SH. [Assessment of malnutrition and relationships with educational achievement of elementary students in Kashan in 1382-83]. Paper presented at the 9th Iranian Nutrition Congress, 4-7 2006, Tabriz, Islamic Republic of Iran. [In Farsi] 